\title{
Family-Centered Care: A Philosophy to be Developed
}

\author{
Antonio Vázquez Sellán, PhD, RN; María Carmen Sellán Soto, PhD, RN²; María Luisa Díaz Martínez, BSc-BA, RN² \\ 'San Rafael-Nebrija Health Sciences University Center, Antonio de Nebrija University, Madrid, Spain \\ ${ }^{2}$ School of Medicine, Autonomous University of Madrid, Madrid, Spain
}

\section{"Corresponding author}

Antonio Vázquez Sellán, PhD, RN

Professor, San Rafael-Nebrija Health Sciences University Center,Antonio de Nebrija University, Madrid, Spain;Tel. (+34) 91 564 I868; E-mail: avazquez@nebrija.es

\section{Article information}

Received: March 24 $4^{\text {th }}$ 2017; Accepted: June 23 ${ }^{\text {rd }}$, 2017; Published: June $23^{\text {rd }}, 2017$

\section{Cite this article}

Vázquez Sellán A, Sellán Soto MC, Díaz Martínez ML. Family-centered care: A philosophy to be developed. Pediatr Neonatal Nurs Open J. 20I7; 5(I): I-5. doi: 10.17I40/PNNOJ-5-126

\section{ABSTRACT}

This article focuses on the philosophy of care such as family-centered care, which is considered beneficial, but their implementation in pediatric units can be clearly improved for the better. Throughout this work, the main difficulties identified in the literature, as well as the important benefits of its implementation involves both the family (children and parents) and the healthcare system have been discussed.

Keywords

Family-centered care (FCC); Pediatric intensive care units (PICU); Neonatal intensive care units (NICU); Healthcare system.

\section{INTRODUCTION}

$\mathrm{T}$ The aim of this paper is to point out how, despite the fact that family-centered care (FCC) is considered to be beneficial, its implementation is far from optimal.

FCC is a philosophy of care that recognizes that the family is a constant in the lives of children and that professionals only act at specific moments. It is the parents and not the professionals who really know the child and their needs. ${ }^{1,2}$ This situation is especially relevant in the case of children with chronic health issues. We will begin this work with a brief review of the evolution of childcare.

\section{A BRIEF HISTORICAL REVIEW}

The United Kingdom (UK) was the first country in which the mother was able to accompany her child during hospitalization. Thus, Sir James Spence, a doctor at the Children's Hospital in Newcastle-upon-Tyne, inaugurated in 1925 the first clinical service to which mothers could accompany their sick children. Two years later in New Zealand, Pickerill and Pickerill let the mother accompany the child to reduce cross-infection. This experience was presented at the end of the 1940s and the results published in 1954. These early attempts at participation were followed by Craig and
McKay, pediatricians at the Royal Aberdeen Hospital for Sick Children in Scotland in 1952. Others would follow suit, culminating with the Platt Report in 1959, drawn up by a multidisciplinary team from the UK. This Report recommended unrestricted visits during child hospitalization; mothers with children under five should have the opportunity to stay in the hospital and that health team training should be improved to include psycho-affective aspects of children and their families.

This gave an important impetus to improving the deplorable conditions of hospitalization in Britain and Europe at that time, introducing innovations in aspects of medical education, planning and architectural design of new hospitals and the creation, in 1961, of Mother Care for Children in Hospital, later known as the National Association for the Welfare of Children in Hospital (NAWCH), which is currently called Action for Sick Children, whose Quality Standard for Care of the Sick Child, established in 1990, is now fully in force in the UK. ${ }^{3}$

In the case of Spain, the first children's hospital dedicated exclusively to care for poor children was the Hospital del Niño Jesús, opened in 1877. The precariousness of that district of Madrid at the end of the $19^{\text {th }}$ century, with a mortality rate of $34 \%$, made this the obvious choice for the location of a hospital for poor children. In this way, children's hospitals were gradually being opened, 
although the real expansion of infant care would take place in the 1960s when the Instituto Nacional de Previsión expanded throughout Spain.

Thus, in each province a hospital, which included a unit of pediatrics and also neonatology, was opened. Although initially only for adults, La Paz, a true hospital complex, was opened in 1964. The following year this hospital added its Children's Hospital and Maternity Hospital, the latter becoming one of the largest maternity hospitals in Europe, with an average of 100 births per day in the 1970s. The Children's Hospital initially had 337 beds and cots, 42 beds for older children and 32 for the mothers of admitted children. Here we find a history of parents' being able to stay with their children. The clear evolution from these first beginnings to the current way of treating and caring for children and their families, suggest that a new philosophy must permeate professional praxis.

So since the second half of the $20^{\text {th }}$ century, child care has undergone a number of significant changes, began to understand that parents were the defenders of their children's rights, and also with the gradual understanding that the child was able to make decisions for herself/himself and that these should be heard.

In this sense, the European Parliament established, on 13 May 1986, the "Rights of the Hospitalized Child", recommendations which were adopted at the United Nations General Assembly on 20 November 1989 (International Convention on the Rights of the Child) and also by United Nations International Children's Emergency Fund (UNICEF), ${ }^{4,5}$

\section{FAMILY-CENTERED CARE (FCC)}

We fully subscribe to the consideration that the family is the basic unit of society. From this starting point, the family's role is set out and constitutes a specification of what we mean by care. Its functions are those ofthe upbringing and socialization of children, and providing assistance to all members of the family for particular needs such as illness or disability.

The central approach of this care philosophy is to understand that family and child form an indivisible unit in which families play a vital role in ensuring the health and well-being of their children. There are different approaches to FCC that slightly modify some of the principles. These can be summarized as follows: ${ }^{2,7,8}$
1. Listen and respect each child and family, taking into account social, cultural, ethnic differences, etc.

2. Ensure that, within health organizations, flexible policies, procedures and practices can be adapted to the needs, beliefs and values of each child and family. Favoring the choice of the child and his/her family on approaches to care.

3. Share the information in a complete, honest and impartial way to allow facilitate decision-making by the families.

4. Recognize and harness the strengths of children and families and enable them to discover their own strengths. Collaborate with them at all levels of healthcare.

This movement arose from the recognition that the separation of parents and children during hospitalization generates significant harm in children, so that, among other modifications, shared decision-making, joint hospitalizations, open doors (free 24 hours visits), visits by siblings, pain management, lactation and breastfeeding support were gradually allowed.

All these changes in the healthcare of the sick child and his family have resulted in several benefits (Table 1) as improve patient outcomes, increase family satisfaction and knowledge of health, reduced unmet healthcare needs, reduced cost, or increase staff satisfaction. ${ }^{9-16}$

Most progress has taken place in the pediatric intensive care units (PICU) and, especially, in the neonatal intensive care units (NICU), due to the development-centered care and linked to the newborn individualized developmental care and assessment program (NIDCAP). ${ }^{17-24}$ Within these units, we have been working to eliminate visiting schedules, promote breastfeeding, implement the Kangaroo Mother Method, promote parent contact with other parents, create parent schools, etc.

For instance, the NICU at Hospital La Paz has an opendoor policy for parents for more than 10 years, and has been promoting breastfeeding for 15 years, and its parents school was set up about ten years ago. Although, Lopez Maestro et $\mathrm{al}^{25}$ shows that there had been an improvement in Spanish public NICUs since his previous research in 2006 , there is still ample room for improvement such as in the implementation of the Kangaroo Mother Method, the availability of rest areas for parents, an open-door policy, or in the use of non-pharmacological methods of pain relief. ${ }^{26}$ Furthermore, it is necessary to bear in mind that Lopez Maestro's research only studied 27 of the 90 NICUs in Spain.

\begin{tabular}{|cc}
\hline Table I. Main Benefits of FCC \\
\hline For child & Improved patient outcomes \\
\cline { 2 - 2 } For parents & Stress reduction \\
\cline { 2 - 2 } & Increased family satisfaction \\
\cline { 2 - 2 } For health system & Build on family and child strengths \\
\cline { 2 - 2 } & Effective use of healthcare resources \\
\hline
\end{tabular}




\begin{tabular}{|ll|}
\hline \multicolumn{2}{|l|}{ Table 2. Main Barriers to FCC } \\
\hline Source & \\
\hline \multirow{2}{*}{ Nurses } & Cultural issues \\
\cline { 2 - 2 } & Communication problems \\
\cline { 2 - 2 } & Reduced ability to meet the physical and psychological needs of the patient and family \\
\cline { 2 - 2 } & Parent-professional collaboration \\
\hline Healthcare system & Orimited time \\
\cline { 2 - 2 } & Financial issues \\
\cline { 2 - 2 } & Continuing education and mentoring programs \\
\hline
\end{tabular}

Although, the majority of scientific societies, including World Health Organization (WHO), support FCC, the reality is that the implementation of this philosophy of care is far from ideal. ${ }^{2,27-29}$ Thus, there are still significant barriers to the implementation of FCC (Table 2). ${ }^{10,30-38}$

\section{CONCLUSIONS}

The literature show that, in general, nurses are aware of the theoretical elements of FCC, but have problems applying them, probably due to a lack of cultural and communication skills. But these issues must be verified in each concrete situation. No research was obtained that addresses the barriers of the health care system identified by nurses, so it's a field that must be studied and explored.

So to generalize FCC practice, it is important to determine the primary obstacles in each case to address the challenges. Therefore, to implement this care model, nurses should not only understand the model conceptually but should also understand the rights, roles, and responsibilities of parents and the potential benefits of providing FCC to families. For us, its important to note that no negative effect has been found for children's health with the implementation of FCC.

Despite the enormous advances in hospitalized children's care and the undoubted advantages, we still have a long way to go in order to achieve an optimal implementation of FCC, at least in Spain.

\section{CONFLICTS OF INTEREST}

The authors declare that there is no conflict of interest.

\section{REFERENCES}

1. Hockenberry MJ. Perspectives of pediatric nursing. In: Hockenberry MJ, Wilson D, Rodgers CC. Wong's Essentials of Pediatric Nursing. $10^{\text {th }}$ ed. St Louis, MO, USA: Elsevier; 2017: 1-14.

2. American Academy of Pediatrics, Committee on Hospital Care and Institute for Patient and Family Centered Care. Patient and family centered care and the pediatrician's role. Pediatrics. 2012; (129): 394-404. doi: 10.1542/peds.2011-3084
3. Barrera F, Moraga F, Escobar S, Antilef R. Participación de la madre y la familia en la atención del niño hospitalizado: Análisis histórico y visión de futuro [In Spanish]. Rev chilpediatr. 2007; 78(1): 85-94. doi: 10.4067/S0370-41062007000100012

4. Carta Europea sobre los Derechos de los Niños Hospitalizados. Resolución del Parlamento Europeo Doc [In Spanish]. A 2-25/86, DOCE 13 de mayo de 1986.

5. Convención sobre los Derechos del Niño, adoptada por la Asamblea General de las Naciones Unidas el 20 de noviembre de 1989 [n Spanish]. BOE» núm. 313, de 31 de diciembre de 1990.

6. ONU, Asamblea General. Seguimiento del décimo aniversario del Año Internacional de la familia. Informe del secretario general, A/64/134 (13.VII.2009) [In Spanish]. 2009. Web site. http:/ / www.un.org/Depts/dhl/resguide/r64sp.sht. Accessed March 23, 2017.

7. Davidson JE, Aslakson RA, Long AC, et al. Guidelines for family-centered care in the neonatal, pediatric, and adult ICU. Crit Care Med. 2017; 45(1): 103-128. doi: 10.1097/CCM. 0000000000002169

8. Kitson A, Marshall A, Bassett K, Zeitz K. What are the core elements of patient-centred care? A narrative review and synthesis of the literature from health policy, medicine and nursing. J Adv Nurs. 2013; 69(1): 4-15. doi: 10.1111/j.1365-2648. 2012.06064.x

9. Shields L. Questioning family-centred care. J Clin Nurs. 2010; 19(17-18): 2629-2638. doi: 10.1111/j.1365-2702.2010.03214.x

10. Foster M, Whitehead L, Maybee P. Parents' and health professionals' perceptions of family centred care for children in hospital, in developed and developing countries: A review of the literature. Int J Nurs Stud. 2010; 47(9): 1184-93. doi: 10.1016/j. ijnurstu.2010.05.005

11. Kuo DZ, Houtrow AJ, Arango P, Kuhlthau KA, Simmons JM, Neff JM. Family-centered care: Current applications and future directions in pediatric healthcare. Matern Child Health J. 2012; 16(2): 297-305. doi: 10.1007/s10995-011-0751-7 
12. Jolley J, Shields L. The evolution of family-centered care. J PediatrNurs. 2009; 24(2): 164-170. doi: 10.1016/j.pedn.2008.03.010

13. Harrison TM. Family-centered pediatric nursing care: State of the Science. J PediatrNurs. 2010; 25(5): 335-343. doi: 10.1016/j. pedn.2009.01.006

14. Shields L, Zhou H, Pratt J, Taylor M, Hunter J, Pascoe E. Family-centred care for hospitalised children aged 0-12 years. Cochrane Database Syst Rev. 2012 17; 10: CD004811. doi: 10.1002/14651858. CD004811.pub3

15. Skene C, Gerrish K, Price F, Pilling E, Bayliss P. Developing family-centred care in a neonatal intensive care unit: An action research study protocol. J Adv Nurs. 2016; 72(3): 658-668. doi: $10.1111 /$ jan.12863

16. Lindly OJ, Geldhof GJ, Acock AC, Sakuma KK, Zuckerman KE, Thorburn S. Family-centered care measurement and associations with unmet healthcare need among US children. Acad Pediatr. 2017; pii: S1876-2859(16)30487-9. doi: 10.1016/j.acap.2016.10.018

17. Davidson JE, Aslakson RA, Long AC, et al. Guidelines for family-centered care in the neonatal, pediatric, and adult ICU. Crit Care Med. 2017; 45(1): 103-128. doi: 10.1097/CCM.0000000000002169

18. McAlvin SS, Carew-Lyons A. Family presence during resuscitation and invasive procedures in pediatric critical care: A systematic review. Am J Crit Care. 2014; 23(6): 477-484. doi: 10.4037/ ajcc2014922

19. Craig JW, Glick C, Phillips R, Hall SL, Smith J, Browne J. Recommendations for involving the family in developmental care of the NICU baby. J Perinatol. 2015; 35(Suppl 1): S5-S8. doi: 10.1038/ jp.2015.142

20. Ramezani T, HadianShirazi Z, Sabet Sarvestani R, Moattari M. Family-centered care in neonatal intensive care unit: A concept analysis. Int J Community Based Nurs Midwifery. 2014; 2(4): 268-278.

21. Purdy IB, Craig JW, Zeanah P. NICU discharge planning and beyond: Recommendations for parent psychosocial support. J Perinatol. 2015; 35(Suppl 1): S24-S28. doi: 10.1038/jp.2015.146

22. Pallás Alonso CR, López Maestro M. NIDCAP, práctica clínica y metanálisis [In Spanish]. Evid Pediatr. 2013; 9: 40.

23. Hall SL, Ryan DJ, Beatty J, Grubbs L. Recommendations for peer-to-peer support for NICU parents. J Perinatol. 2015; 35(Suppl 1): S9-S13. doi: 10.1038/jp.2015.143

24. Roué J-M, Kuhn P, Lopez Maestro M, et al. Eight principles for patient-centred and family-centred care for newborns. Arch Dis Child Fetal Neonatal Ed. 2017; 0: F1-F5. doi: 10.1136/archdischild-2016-312180

25. López MM, Bonis AM, de la Cruz-Bertolo J, Perapoch LJ, Peña
RM, Alonso CP. Cuidados centrados en el desarrollo. Situación en las unidades de neonatología de España [In Spanish]. An Pediatr (Barc). 2014; 81(4): 232-240. doi: 10.1016/j.anpedi.2013.10.043

26. Perapoch López J, Pallás Alonso CR, Linde Sillo MA, et al. Cuidados centrados en el desarrollo. Situación en las unidades de neonatología de España [In Spanish]. An Pediatr (Barc). 2006; 64: 132-139. doi: $10.1157 / 13084172$

27. Walter JK, Benneyworth BD, Housey M, Davis MM. The factors associated with high-quality communication for critically ill children. Pediatrics. 2013; 131(Suppl 1): 90-95. doi: 10.1542/ peds.2012-1427k

28. Torres-Ospina JN, Vanegas-Díaz CA, Yepes-Delgado CE. Atención centrada en el paciente y la familia en la unidad de cuidado intensivo pediátrica del hospital Pablo Tobón Uribe, sistematización de la experiencia [In Spanish]. Rev Gerenc Polít Salud. 2016; 15(31): 190-201. doi: 10.11144/Javeriana.rgyps15-31.acpf

29. World Health Organization [Internet]. Geneva: People at the Centre of Care; 2017. Web site. http://www.wpro.who.int/health_ services/people_at_the_centre_of_care/definition/en/.Accessed March 5, 2017.

30. Coyne I, O’Neill C, Murphy M, Costello T, O’Shea R. What does family-centred care mean to nurses and how do they think it could be enhanced in practice. J Adv Nurs. 2011; 67(12): 25612573. doi: 10.1111/j.1365-2648.2011.05768.x

31. Feeg VD, Paraszczuk AM, Çavuşoğlu H, Shields L, Pars H, $\mathrm{Al}$ Mamun A. How is family centered care perceived by healthcare providers from different countries? An international comparison study. J Pediatr Nurs. 2016; 31(3): 267-276. doi: 10.1016/j. pedn.2015.11.007

32. Hughes M. Parents' and nurses' attitudes to family-centred care: An Irish perspective. J Clin Nurs. 2007; 16(12): 2341-2348. doi: 10.1111/j.1365-2702.2007.01967.x

33. Regan KM, Curtin C, Vorderer L. Paradigm shifts in inpatient psychiatric care of children: Approaching child- and family-centered care. J Child Adolesc Psychiatr Nurs. 2006; 19(1): 29-40. doi: 10.1111/j.1744-6171.2006.00040.x

34. Craft-Rosenberg M, Kelley P, Schnoll L. Family-centered care: Practice and preparation. Fam Soc. 2006; 87(1): 17-25.

35. Boztepe H, KerimoğluYıldız G. Nurses perceptions of barriers to implementing family-centered care in a pediatric setting: A qualitative study. J Spec PediatrNurs. 2017; 22(2). doi: 10.1111/ jspn.12175

36. Alabdulaziz H, Moss C, Copnell B. Paediatric nurses' perceptions and practices of family-centred care in Saudi hospitals: A mixed methods study. Int J Nurs Stud. 2017; 69: 66-77. doi: 10.1016/j.ijnurstu.2017.01.011 
37. Bleser WK, Young SI, Miranda PY. Disparities in patient- and family-centered care during US children's healthcare encounters: A closer examination. Acad Pediatr. 2017; 17(1): 17-26. doi: 10.1016/j. acap.2016.06.008
38. Boztepe H, Kerimoğlu Yıldız G. Nurses perceptions of barriers to implementing family-centered care in a pediatric setting: A qualitative study. J Spec Pediatr Nurs. 2017; 22(2). doi: 10.1111/ jspn. 12175 